\title{
Analysis of Factors Related to Mother Motivation In the Provision of Basic Immunization in Baby Age 0-9 Months in Puskesmas Working Area South Alalak Banjarmasin
}

\author{
* Angga Irawan ${ }^{1}$, Rifa'atul Mahmudah ${ }^{2}$, Muhammad Hatta Subakti ${ }^{3}$ \\ * Email: angga_irawan10@yahoo.co.id
}

\begin{abstract}
One of the efforts to control the disease is through immunization. Low immunization coverage indicates low motivation in basic immunization. Factors that influence motivation include knowledge, perception and family support. To determine factors related to maternal motivation regarding basic immunization in infants aged 0-9 months. The study used analytic survey with cross sectional approach. The population is all mothers of infants aged 0-9 months in the work area of the South Alalak Health Center in Banjarmasin, amounting to 711 people. Samples taken amounted to 98 people with purposive sampling technique. Data were analyzed using the Spearman Rank test with a 95\% confidence level. Most of the mothers did not know about immunization, 64 people $(65.3 \%)$, had sufficient perception that 86 people $(87.8 \%)$, had family support of 78 people (79.6\%), had high motivation regarding the provision of basic immunizations, 54 people $(55.1 \%)$. There is a relationship between knowledge, perceptions and family support with mother's motivation regarding basic immunization in infants aged 0-9 months. There is a relationship between knowledge, perceptions and family support with mother's motivation regarding basic immunization for infants aged 0-9 months. Puskesmas should be able to improve communication, information and education media on basic immunization in full through posters, or leaflets.
\end{abstract}

Keywords: Family Support, Basic Immunization, Motivation, Knowledge, Perception.

\section{Introduction}

One effort in controlling disease is through immunization. According to estimates by the World Health Organization (WHO), more than 12 million children aged less than 5 years who die every year in the world, about 2 million children are caused by diseases that can be prevented by immunization and nearly $20 \%$ occur in children due to incomplete basic immunization status (Nuraini, 2013). Diseases that can be prevented through immunization are diphtheria, measles, pertussis, pneumonia, polio, rotavirus diarrhea, rubella, and tetanus through immunization. However, there are still around 22 million babies in the world who have not yet received complete 
immunization and as many as 9.5 million exist in Southeast Asia including children in Indonesia (Kemenkes RI, 2014).

Basic Health Research Data (Riskesdas) in 2013 the percentage of complete basic immunization in children in Indonesia was $59.2 \%$ complete, $32.1 \%$ did not get incomplete immunization and as many as $8.7 \%$ of children did not get immunized while in South Kalimantan Province children 52\% of those who have completed immunizations, $33.9 \%$ incomplete and $14 \%$ of children who cannot get immunizations (Ministry of Health, Republic of Indonesia, 2013).

Components in immunizing infants include, among others, parents whose mothers do not routinely bring children under five to visit the Puskesmas to be immunized. Factors that influence maternal behavior in giving immunizations to children are motivation (Tampemawa, 2015).

Mother's motivation will be stronger because it is influenced by needs, hopes and interests, family encouragement, the environment and also the media (Utami, 2014). Factors that influence motivation are intrinsic and extrinsic factors. Intrinsic factors are factors that arise from within the self, namely knowledge, age, perception, expectations, needs, education while extrinsic factors consist of work, cultural and environmental status (Fauzi, 2015).

Lack of knowledge about immunization can cause a mother's lack of motivation in giving immunizations to her baby (Nugraha, 2011). High perception will encourage a good motivation to carry out an activity, one of which is a mother who has just given birth requires a high perception of both internal and external factors to motivate her to carry out a certain activity in achieving goals by giving complete basic immunization to her baby (As'ad, 2016)

Data from the Banjarmasin City Health Office from January to November 2016 shows that of 13,386 babies born alive, only 7,611 people (56.9\%) received complete immunizations. The lowest percentage of babies who received complete immunization was found in the working area of the South Alalak Health Center, from 711 babies born alive to only 223 people (31.4\%) babies born alive who received complete immunizations.

The results of a preliminary study through a short interview with 10 mothers of infants aged 0 9 months in the work area of the Alalak Selatan Health Center in Banjarmasin obtained as many as 6 people $(60 \%)$ said their children had not received the immunization according to the advice of health workers and $4(40 \%)$ said that his son has been getting immunizations according to the advice of health workers.

Based on the above background, the researcher is interested in conducting a study entitled "Factors Associated with Mother's Motivation on Provision of Basic Immunization in Infants Age 0-9 Months in the Work Area of the South Alalak Health Center in Banjarmasin".

\section{Methods}

The method used in this research is analytic survey with cross sectional approach. The population in this study were all mothers of infants aged 0-9 months in the work area of the Alalak 
Selatan Health Center in Banjarmasin, which amounted to 711 people and samples taken amounted to 98 people with sampling technique porpusive sampling.

\section{Results}

\subsection{Univariate analysis}

\subsubsection{Mother's knowledge of basic immunization in infants aged 0-9 months}

The frequency distribution of maternal knowledge about basic immunization in infants aged 09 months in the work area of the South Alalak Health Center in Banjarmasin can be seen in the following table:

Table 1. Frequency Distribution of Mother's Knowledge of Basic Immunization in Infants Age 0-9 months in the working area of South Alalak Health Center Banjarmasin March 2017.

\begin{tabular}{clcc}
\hline No. & Knowledge & $\begin{array}{c}\text { Frequenvy } \\
(\mathrm{n})\end{array}$ & $\begin{array}{c}\text { Persentase } \\
(\%)\end{array}$ \\
\hline 1 & Less & 64 & 65,3 \\
2 & Enough & 24 & 24,5 \\
3 & Good & 10 & 10,2 \\
\hline & Amount & 98 & 100 \\
\hline
\end{tabular}

Based on table 1, it was found that most mothers' knowledge about basic immunization with less categories is 64 people $(65.3 \%)$.

\subsubsection{Maternal perceptions of basic immunization in infants aged 0-9 months}

The frequency distribution of mothers' perceptions of basic immunization in infants aged 0-9 months in the work area of the South Alalak Health Center in Banjarmasin can be seen in the following table: 
Table 2. Distribution of the Frequency of Mother's Perceptions of Basic Immunization in Infants Age 0-9 months in the working area of South Alalak Health Center Banjarmasin in March 2017.

\begin{tabular}{|c|c|c|c|}
\hline No. & Perception & $\begin{array}{c}\text { Frekuensi } \\
\text { (n) }\end{array}$ & $\begin{array}{c}\text { Persentase } \\
(\%)\end{array}$ \\
\hline 1 & Less & 0 & 0 \\
\hline 2 & Enough & 86 & 87,8 \\
\hline 3 & Good & 12 & 12,2 \\
\hline \multicolumn{2}{|c|}{ Amount } & 98 & 100 \\
\hline
\end{tabular}

Based on table 2, it was found that most mothers' perceptions of basic immunizations with sufficient categories were 86 people $(87.8 \%)$.

\subsubsection{Family support for basic immunization in infants aged 0-9 months}

The frequency distribution of family support for basic immunization in infants aged 0-9 months in the work area of the South Alalak Health Center in Banjarmasin can be seen in the following table:

Table 3. Frequency Distribution of Family Support for Basic Immunization in Infants Age 0-9 months in the working area of South Alalak Health Center Banjarmasin March 2017.

\begin{tabular}{clcc}
\hline No. & $\begin{array}{c}\text { Family } \\
\text { support }\end{array}$ & $\begin{array}{c}\text { Frekuensi } \\
(\mathrm{n})\end{array}$ & $\begin{array}{c}\text { Persentase } \\
(\%)\end{array}$ \\
\hline 1 & Poor support & 20 & 20,4 \\
2 & Support & 78 & 79,6 \\
\hline & Amount & 98 & 100 \\
\hline
\end{tabular}

Based on table 3, it was found that the family of 0-9 month old mothers mostly supported the basic immunization, namely 78 people $(79.6 \%)$. 


\subsubsection{Mother's motivation about basic immunization in infants aged 0-9 months}

The frequency distribution of mother's motivation regarding basic immunization for infants aged 0-9 months in the work area of the South Alalak Health Center in Banjarmasin can be seen in the following table:

Table 4. Frequency Distribution Motivation of mothers regarding basic immunization for infants aged 0-9 months in the working area of Alalak Selatan Health Center Banjarmasin in March 2017.

\begin{tabular}{clcc}
\hline No. & Motivation & $\begin{array}{c}\text { Frekuensi } \\
\text { (n) }\end{array}$ & $\begin{array}{c}\text { Persentase } \\
(\%)\end{array}$ \\
\hline 1 & Low & 44 & 44,9 \\
2 & Height & 54 & 55,1 \\
\hline & Amount & 98 & 100 \\
\hline
\end{tabular}

Based on table 4 it was found that most mothers have high motivation to provide complete basic immunization in infants from 0 to 9 months namely 54 people $(55.1 \%)$.

\subsection{Bivariate analysis}

\subsubsection{Relationship of knowledge with mother's motivation about basic immunization in infants aged 0-9 months.}

Analysis of the relationship of knowledge with maternal motivation regarding basic immunization in infants aged 0-9 months can be seen in the following table. 
Table 5. Analysis of the relationship of knowledge with maternal motivation regarding basic immunization in infants aged 0-9 months

\begin{tabular}{|c|c|c|c|c|c|c|c|}
\hline \multirow{3}{*}{$\begin{array}{l}\mathrm{N} \\
\mathrm{o} .\end{array}$} & \multirow{3}{*}{$\begin{array}{c}\text { Knowledg } \\
\text { e }\end{array}$} & \multicolumn{4}{|c|}{ Motivation } & \multirow{2}{*}{\multicolumn{2}{|c|}{ Amount }} \\
\hline & & \multicolumn{2}{|c|}{ Low } & \multicolumn{2}{|c|}{ High } & & \\
\hline & & $\mathrm{f}$ & $\%$ & $\mathrm{f}$ & $\%$ & $\mathrm{f}$ & $\%$ \\
\hline 1 & Less & 41 & 64,1 & 23 & 35,9 & 64 & 100 \\
\hline 2 & Enough & 3 & 12,5 & 21 & 87,5 & 24 & 100 \\
\hline 3 & Good & 0 & 0 & 10 & 100 & 10 & 100 \\
\hline & Amount & 44 & 44,9 & 54 & 55,1 & 98 & 100 \\
\hline & \multicolumn{3}{|c|}{$\mathrm{p}$ value $=0,000$} & \multicolumn{2}{|c|}{$\mathrm{r}=0,532$} & & \\
\hline
\end{tabular}

Based on table 5 shows that from mothers who lack knowledge about basic immunization most have low motivation in providing complete basic immunization as many as 41 people (64.1\%), mothers who have sufficient knowledge mostly have high motivation in providing complete basic immunization as many as 21 people $(87.5 \%)$ while mothers who have good knowledge all have high motivation to provide complete basic immunization in infants of 0-9 months, as many as 10 people $(100 \%)$.

Spearman Rank statistical test results obtained $\mathrm{p}=0,000$, then $\mathrm{p}<\alpha$, it can be concluded that $\mathrm{Ho}$ is rejected and $\mathrm{Ha}$ is accepted, meaning that there is a relationship between mother's knowledge and motivation about basic immunization in infants aged 0-9 months in the work area of Alalak Selatan Health Center Banjarmasin.

The Spearman Rank correlation value of 0.532 shows that the direction of the positive correlation with the strength of a strong correlation can be interpreted the better the mother's knowledge about basic immunization, the higher the motivation to provide a complete basic immunization until the baby is 9 months old. 


\subsubsection{Relationship of perception with maternal motivation regarding basic immunization in infants aged 0-9 months}

Analysis of the relationship of perception with maternal motivation regarding basic immunization in infants aged 0-9 months can be seen in the following table.

Table 6. The Relationship of Perception with Mother's Motivation on Provision of Basic Immunization in Infants Age 0-9 Months in the Work Area of South Alalak Health Center

Banjarmasin in March 2017

\begin{tabular}{|c|c|c|c|c|c|c|c|}
\hline \multirow{3}{*}{$\begin{array}{l}\mathrm{N} \\
\text { o. }\end{array}$} & \multirow{3}{*}{$\begin{array}{c}\text { Percept } \\
\text { ion }\end{array}$} & \multicolumn{4}{|c|}{ Motivation } & \multirow{2}{*}{\multicolumn{2}{|c|}{ Amount }} \\
\hline & & \multicolumn{2}{|c|}{ Low } & \multicolumn{2}{|c|}{ High } & & \\
\hline & & $\mathrm{f}$ & $\%$ & $\mathrm{f}$ & $\%$ & $\mathrm{f}$ & $\%$ \\
\hline 1 & Less & 0 & 0 & 0 & 0 & 0 & 0 \\
\hline 2 & Enough & 44 & 51,2 & 42 & 48,8 & 86 & 100 \\
\hline 3 & Well & 0 & 0 & 12 & 100 & 12 & 100 \\
\hline \multicolumn{2}{|c|}{ Amount } & 44 & 44,9 & 54 & 55,1 & 98 & 100 \\
\hline
\end{tabular}

Based on table 6 shows that most of the mothers who have a good perception of basic immunization have low motivation in providing complete basic immunization as many as 44 people $(51.2 \%)$ while mothers who have good perception all have motivation high level to provide complete basic immunization in infants of 0-9 months, as many as 12 people (100\%).

Spearman Rank statistical test results obtained $p=0.001$, then $p<\alpha$, it can be concluded that $\mathrm{Ho}$ is rejected and $\mathrm{Ha}$ is accepted, meaning that there is a relationship between perceptions with maternal motivation regarding basic immunization for infants aged 0-9 months in the work area of Alalak Selatan Health Center Banjarmasin.

The Spearman Rank correlation value of 0.337 indicates that the direction of the positive correlation with the strength of the moderate correlation can be interpreted as the better the mother's perception of basic immunization, the higher the motivation to provide a complete basic immunization until the baby is 9 months old.Relationship of family support with maternal motivation regarding basic immunization in infants aged 0-9 months

Analysis of the relationship of family support with maternal motivation regarding basic immunization for infants aged 0-9 months in the working area of the South Alalak Health Center in Banjarmasin can be seen in the following table. 
Table 7. Relationship between Family Support and Mother's Motivation on Provision of Basic Immunization in Infants Age 0-9 Months in the Work Area of South Alalak Health Center Banjarmasin in March 2017.

\begin{tabular}{|c|c|c|c|c|c|c|c|}
\hline \multirow{3}{*}{$\begin{array}{l}\mathrm{N} \\
\text { o. }\end{array}$} & \multirow{3}{*}{$\begin{array}{l}\text { Family } \\
\text { Support }\end{array}$} & \multicolumn{4}{|c|}{ Motivation } & \multirow{2}{*}{\multicolumn{2}{|c|}{ Amount }} \\
\hline & & \multicolumn{2}{|c|}{ Low } & \multicolumn{2}{|c|}{ High } & & \\
\hline & & $f$ & $\%$ & $\mathrm{f}$ & $\%$ & $f$ & $\%$ \\
\hline 1 & $\begin{array}{l}\text { Less } \\
\text { support }\end{array}$ & 14 & 70 & 6 & 30 & 20 & 0 \\
\hline 2 & Supports & 30 & 38,5 & 48 & 61.5 & 78 & 100 \\
\hline \multicolumn{2}{|c|}{ Amount } & 44 & 44,9 & 54 & 55,1 & 98 & 100 \\
\hline
\end{tabular}

$\mathrm{p}$ value $=0,011, \quad \mathrm{r}=0,256$

Based on table 7 shows that mothers who have less supportive families mostly have low motivation in providing complete basic immunization as many as 14 people $(70 \%)$ while mothers who have families that support basic immunization mostly have high motivation to provide basic immunizations that are complete in infants $0-9$ months, as many as 48 people $(61.5 \%)$.

Spearman Rank statistical test results obtained $p=0.011$, then $p<\alpha$, it can be concluded that Ho is rejected and Ha is accepted, meaning that there is a relationship between family support and maternal motivation regarding basic immunization for infants aged 0-9 months in the working area of Alalak Selatan Health Center Banjarmasin.

Spearman Rank correlation value of 0.256 shows that the direction of a positive correlation with the strength of a weak correlation can be interpreted as the better supported by the family, the higher the mother's motivation to provide complete basic immunization until the baby is 9 months old.

\section{Discussion}

\subsection{Mother's knowledge of basic immunization in infants aged 0-9 months in the work area of the South Alalak Health Center in Banjarmasin.}

The results showed that most mothers knowledge about basic immunization with less categories is 64 people (65.3\%). The data shows that many respondents still do not know about the definition of basic immunization, types of basic immunizations, the time of basic immunization, the benefits of basic immunization as well as the frequency and manner of immunization.

The low knowledge of mothers who have babies aged 0-9 months in the work area of the South Alalak Health Center can be caused by the lack of exposure to basic immunization information obtained from the experiences of themselves, health workers and the environment from the surrounding community. The results of this study are the same as the results of a study conducted by Anggraeni (2015) who said that the majority of mothers of infants at the Salam City Health Center in Bandung had less knowledge about basic immunization as many as 21 people (43.75\%), then 9 people ( $18.75 \%$ ) have enough knowledge and only 18 people (37.5\%) with good knowledge. 
The results of this study are not in line with the results of research conducted by Sari (2015) who said that most mothers in the working area of Bendo Health Center in Magetan Regency have good knowledge of basic immunization as many as 34 people (52.3\%).

\subsection{Mother's perception of basic immunization in infants aged 0-9 months in the working area of South Alalak Health Center, Banjarmasin.}

The results of this study found that most mothers' perceptions of basic immunizations with sufficient categories were 86 people $(87.8 \%)$. These data indicate that the views or responses of mothers to basic immunization in infants aged 0-9 months have not been good. This can be caused by the fact that there is still a lot of lack of knowledge about basic immunization itself, so that some of them still perceive it wrong.

The results of this study indicate that mothers view or interpret basic immunizations as good enough. It is expected that with the good perception of mothers about basic immunization will be able to create a good behavior as well while in mothers who have enough and less perceptions of basic immunization a good approach should be done directly, the mother needs to be explained about the importance of basic immunization in full.

The results of this study are the same as those of Istiana (2016) who said that most of the parents in the working area of the Kalikotes Klaten Puskesmas have sufficient knowledge about immunization, as many as 14 people $(46.67 \%)$.

The results of this study are not in line with the results of research conducted by Arini (2009) which said that mothers in BPS Indarwati Mranggen Jatinom Klaten as many as 17 people (63.6\%) had good perceptions about immunization and quite good perceptions of 11 people (36.7\%) and 2 people $(6.7 \%)$ had poor perception.

\subsection{Family support for mothers to provide basic immunization for infants aged 0-9 months in the working area of South Alalak Health Center, Banjarmasin.}

The results showed that the family of $0-9$ month old mothers mostly supported basic immunization, namely 78 people $(79.6 \%)$. The data explains that most of the mothers of infants actually have received assistance or assistance from family members regarding basic immunization in the form of information, intrumental, emotional and an assessment of the complete basic immunization.

Respondents who have family from basic immunization can be interpreted that the respondent is given full freedom to complete basic immunization to the baby. The family is the most important source of social support, so it can be concluded that the high level of support is due to the high concern of the family for the respondent and their children so that the respondent feels valued and 
cared for. Family support is needed to live a life including maintaining a baby's health through giving full immunizations.

The results of this study are the same as Hermayanti's research (2016) which says that mothers of infants at the Sungai Pinang Hulu Sungai Selatan Public Health Center mostly have family support for immunization as many as 56 people (73.7\%).

The results of this study are not in line with the results of research conducted by Hafid (2016) which says that mothers in the Konang and Geger Health Centers in Bangkalan District partially do not have family support in providing immunizations to babies as many as 157 people (57.1\%).

\subsection{Motivation of mothers regarding basic immunization for infants aged 0-9 months in the work area of South Alalak Health Center, Banjarmasin.}

The results showed that most mothers have high motivation to provide complete basic immunization in infants $0-9$. The results showed that most mothers have high motivation to provide complete basic immunization in infants of $0-9$ months, namely 54 people $(55.1 \%)$. The data shows that some mothers have been motivated to provide basic immunizations in accordance with the provisions set by the government, but some have shown the lack of enthusiasm of mothers to provide complete basic immunizations to infants. Providing complete immunization requires motivation in achieving the completeness of the immunizations that have been set, with the motivation of the mother will have a high enthusiasm to provide immunizations to the baby. The existence of motivation can function to encourage and move the mother to provide immunization so as to obtain maximum results.

The results of this study are the same as those of Sulistyani (2014) who said that mothers of infants at the Kedungwuni I Health Center in Pekalongan Regency mostly had high motivation in providing complete basic immunizations to infants, as many as 43 people $(51.2 \%)$.

The results of this study are not in line with the results of Kusumawati's research (2015) which says that most mothers at BPM Suharijati Surabaya have low motivation in giving complete immunizations to infants, as many as 18 people $(60 \%)$.

\subsection{Relationship of knowledge with mother's motivation about basic immunization for infants aged 0-9 months in the working area of Banjarmasin Puskesmas.}

The results showed that most mothers who lack knowledge about basic immunization have low motivation in providing complete basic immunization, as many as 41 people $(64.1 \%)$, mothers who 
have sufficient knowledge, most of whom have high motivation to provide complete basic immunization as many as 21 people $(87.5 \%)$ while mothers who have good knowledge all have high motivation to provide complete basic immunization in infants of $0-9$ months, as many as 10 people $(100 \%)$.

Statistical test results show the relationship between knowledge and mother's motivation regarding basic immunization for infants aged 0-9 months in the working area of South Alalak Health Center, Banjarmasin. Knowledge is one of the internal factors of motivation, so if the mother has good knowledge about the benefits of basic immunization, it is hoped that she will have high motivation in providing complete basic immunization.

Mother's knowledge of good immunization affects the motivation of mothers in immunizing their babies. A mother will be encouraged to bring her baby to be immunized if a mother understands what the benefits of immunization for her baby, a mother's understanding and knowledge of the completeness of basic immunization against the baby will have an influence on the immunization of her baby.

Knowledge is the initial stage where respondents begin to recognize new ideas and learn to understand basic immunizations that can ultimately encourage mothers to provide basic immunizations to babies in full. The better the mother's knowledge about basic immunization, the higher the mother's urge to increase the mother's willingness to provide basic immunizations to the baby in full.

The results of this study are the same as the results of research conducted by Nugraha (2011) stating that there is a relationship between maternal knowledge about basic immunization and mother's motivation to provide immunizations to infants in Bawen Health Center, Bawen District, Semarang $(\mathrm{p}$ value $=0.0042<\alpha 0.05)$.

\subsection{Relationship of perception with mother's motivation regarding basic immunization for infants aged 0-9 months in the working area of Banjarmasin Public Health Center.}

The results of research from mothers who have a fairly good perception of basic immunization mostly have low motivation in providing a complete basic immunization as many as 44 people $(51.2 \%)$ while mothers who have good perceptions all have high motivation to provide immunizations complete base in infants from 0 to 9 months is as many as 12 people (100\%).

The results of statistical tests show that there is a relationship between perception and mother's motivation regarding basic immunization for infants aged 0-9 months in the working area of South Alalak Health Center, Banjarmasin. A good perception will encourage to increase high motivation to do an activity, one of which is a mother who has a baby aged 0-9 months requires a good 
perception of internal and external factors to motivate her to carry out certain activities in achieving goals by giving complete basic immunization of the baby.

\subsection{Relationship between family support and mother's motivation regarding basic immunization for infants aged 0-9 months in the working area of Banjarmasin Public Health Center}

The results showed that most mothers who lack family support had low motivation in providing complete basic immunization, as many as 14 people (70\%) while mothers who had families that supported basic immunization mostly had high motivation to provide complete basic immunizations. in infants $0-9$ months, as many as 48 people $(61.5 \%)$.

Statistical test results show there is a relationship between family support and maternal motivation regarding basic immunization for infants aged 0-9 months in the work area of South Alalak Health Center Banjarmasin. Family support is very useful to increase respondent motivation in providing complete immunization to infants, so it can be said that if family support is good, motivation for giving complete immunization will be higher and vice versa if family support is lacking then motivation for giving complete immunization will decrease. Family support is needed to help respondents motivate to provide complete immunizations to infants so that respondents can work independently in providing immunizations.

The results of this study are the same as the results of research conducted by Utami (2014) stating there is a relationship between family support and mother's motivation in obtaining complete basic immunization in West Nyabakan village ( $\mathrm{p}$ value $=0,000<\alpha 0.05$ ). 


\section{References}

[1] Anggraeni, A. Hubungan tingkat pengetahuan ibu tentang imunisasi dasar lengkap dengan kepatuhan melaksanakan imunisasi di Puskesmas Salam Kota Bandung. Vol 1 (1). 629-633. (2015)

[2] Arini, M. Y. Hubungan persepsi ibu dengan status imunisasi polio pada bayi di Bidan Praktek Swasta Indarwati Mranggen Jatinom Klaten. Vol. 1 (1). 1-7. (2009)

[3] As'ad, M. Hubungan persepsi dengan motivasi ibu primipara dalam imunisasi dasar lengkap pada bayi di Desa Ambunten Barat Kecamatan Ambunten Kabupaten Sumenep. Vol. 1 (1). 1-8. (2016)

[4] Dinas Kesehatan Kota Banjarmasin. Laporan Bulanan Januari - November 2016. Banjarmasin. Dinas Kesehatan Kota Banjarmasin. (2016)

[5] Fauzi, L. Faktor-faktor intrinsik yang mempengaruhi motivasi perawat dalam penanganan pasien cedera kepala di Instalasi Gawat Darurat RSUD Karangayar [Internet], tersedia dalam: http://stikeskusumahusada.ac.id/digilib/download.php?id=1330 [diakses tanggal 16 Desember 2016]. (2015)

[6] Hafid, W. Faktor determinan status imunisasi dasar lengkap pada bayi di Puskesmas Konang dan Geger Kabupaten Bangkalan. Vo. 3 (1). 38-44. (2016)

[7] Hamidin, A. S. Imunisasi Alami untuk Anak. Jakarta: Saufa.(2014)

[8] Istiana, N. H. Hubungan persepsi orang tua tentang imunisasi dengan kelengkapan imunisasi hepatitis B dengan anaknya di wilayah kerja Puskesmas Kalikotes Klaten. Vol. 1 (1). 1-10. (2016)

[9] Kementerian Kesehatan RI. 2013. Riset kesehatan dasar [Internet], tersedia dalam: http://labdata.litbang.depkes.go.id [diakses tanggal 04 Desember 2016]. (2013)

[10] Kementerian Kesehatan RI. Imunisasi untuk masa depan lebih sehat [Internet], tersedia dalam: http://www.depkes.go.id [diakses tanggal 04 Desember 2016]. (2014)

[11] Kusumati, D. W. D. Studi motivasi dan kelengkapan imunisasi pada bayi usia 12 bulan di BPM Suharijati Surabaya [Internet], tersedia dalam: http://repository.unusa.ac.id/1084/ [diakses tanggal 11 Mei 2017]. (2015)

[12] Nugraha, W. A. M. Hubungan antara Pengetahuan ibu tentang Imunisasi dasar dengan motivasi ibu untuk memberikan imunisasi kepada bayi di Puskesmas Bawen Kecamatan Bawen. Vol. 1 (1). 1-9. (2011)

[15] Nuraini, V. A. Faktor-faktor yang berhubungan dengan kelengkapan imunisasi dasar pada bayi di Desa Truko Kecamatan Kangkung Kabupaten Kendal. Vol. I (1). 1-15. (2013)

[16] Sari, D. N. I. S. Hubungan pengetahuan ibu tentang imunisasi dasar dengan kelengkapan imunisasi dasar pada bayi di wilayah kerja Puskesmas Bendo Kabupaten Magetan. Vol. (8) No. 2. 6-12. (2015)

[17] Sulistyani, .D. Hubungan tingkat kecemasan ibu pasca imunisasi dengan motivasi ibu memberikan imunisasi dasar lengkap pada anak usia 0-12 bulan di Puskesmas Kedungwuni I Kabupaten Pekalongan [Internet], tersedia dalam: http://jurma.unimus.ac.id/index.php/perawat/article/viewFile/268/268 [diakses tanggal 05 Mei 2017]. (2014)

[18] Tampemawa, R. J. E. Hubungan pengetahuan, sikap dan motivasi ibu tentang imunisasi dengan status imunisasi anak usia 12-24 bulan di Pusat Kesehatan Masyarakat Ranotana Weru Kota Manado. Vol. I (1). 1-7. (2015)

[19] Utami, R.. Hubungan dukungan keluarga dengan motivasi ibu dalam mendapatkan imunisasi dasar lengkap pada bayi usia 0-12 bulan di Desa Nyabakan Barat. Vol. I (1). 44-52. (2014) 
